\title{
ASYMMETRY IN FARM-RETAIL PRICE TRANSMISSION: THE CASE OF CHILI INDUSTRY IN INDONESIA
}

\author{
Sahara $^{1}$, and Bagus Wicaksena ${ }^{2}$ \\ ${ }^{1}$ lecturer in Department of Economics, Bogor Agricultural University and Deputy \\ Director in International Center for Applied Finance and Economics \\ ${ }^{2}$ Staff/Junior Researcher Center for Domestic Trade Policy, Trade Policy Analysis and \\ Development Agency, Ministry of Trade, Indonesia
}

Artikel diterima Februari 2013

Artikel disetujui untuk dipublikasikan Juli 2013

\begin{abstract}
A decade of strong economic growth and rapid urbanization are transforming Indonesia's food retail sector. In particular, supermarkets and related modern retail outlets are reorganizing how high value fruit and vegetable supply chains operate, effecting quantities, varieties, quality and prices. Among the agricultural development issues facing Indonesia's policymakers are efficiency and distributional consequences of these transforming fruit and vegetable markets. This study examines asymmetric price transmission in chili supply chains to assess emerging market failures and potential equity implications for producers and consumers. The Indonesian government recognizes chilies as one of its 10 priority crops. Chilies are produced by more than 400,000 small scale producers and are an essential ingredient in the Indonesian daily diet. Historically, chili markets have exhibited large price fluctuations in Indonesia. Two methods for examining asymmetric price transmission are compared using monthly data over an 18 year period in Java: Houck's model and the Error Correction Model (ECM). Although commonly believed that modern retail sectors are increasing market power and influencing prices, both models suggest that there is no price asymmetry issue in the chili supply chain in Indonesia.
\end{abstract}

Key word: chili, price, asimetric, transmission

\section{INTRODUCTION}

For a variety of reasons, including rapid growth of income per capita, liberalization of trade, foreign direct investment and urbanization, modern market chains have penetrated rapidly in to developing countries (Reardon and Berdegué, 2002; Reardon et al., 2004). Similar situations occur in Indonesia where in 1970 only one supermarket was available and since 2008 around 11,868 modern markets have been operating in Indonesia particularly in JavaIsland. During 2004-2008 the number of modern markets- minimarket, supermarket and hypermarket- increased significantly by about 80.23 percent
(Indonesia Retailers Association and MediaData in Pandin, 2009). The dramatic increase in supermarket chains has led to a transformation of the supply chains of High Value Agricultural Products (HVAPs) in terms of improving on quality and food safety standard, prices and consistency in supply of HVAPs (Weatherspoon and Reardon, 2003; Reardon et al., 2004). Such situations lead to efficiency issue as well as distributional consequences in the agricultural development particularly in HVAPs.

One of important HVAPs in Indonesia is chili that including as 10 priority crops producing by more than 400,000 small scale producers and are an 
essential ingredient in the Indonesian daily diet (Ministry of Agricultural, cited in AGRINA, 2009). The chili crop exhibits a large price fluctuation and many people feel that the chili price transmission from producer and consumer levels are not transmitted in the same speed. Although price asymmetry exists in most agricultural products, no studies confirm the asymmetric price issue in the chili supply chain in Indonesia.

Analyzing price asymmetry is important in providing information about the welfare between producers and consumers, as well as, as an indicator of price efficiency in the marketing channel (Balcombe, et.al., 2007; Cutts and Kirsten, 2006; Koutroumanidis, et al., 2009; Miller and Hayenga, 2001). Evidence of asymmetric price transmission indicates that a group is not benefiting from a price reduction (consumers) or increase (producers) that would, under conditions of symmetry, have taken place sooner (Meyer and v. Cramon-Taubadel, 2004). Furthermore, the slow response of price changes between producer and consumer levels show inefficiency and inequity of price transmission in the marketing channel (Miller and Hayenga (2001).

\section{CURRENT ECONOMIC SITUATIOMN OF CHILI IN INDONESIA}

Indonesia is one of the major countries that produce chili in the world although only a small amount of fresh chilies are traded from Indonesia to international markets (on average 739.48 tones and 155.99 of chilies are exported and imported respectively during 19962007), the value of chili trade balance tended to increase, indicating the potential market at the international level.

The recent data also indicate an increasing trend in the chili contribution to Indonesian horticultural sector as well as its production aspect. In 1992 the contribution of chili to the value of horticulture sector only $0.25 \%$ and reached around $3.54 \%$ in 2007 (Department of Agriculture, 2008 ${ }^{\mathrm{b}}$ and Central Bureau of Statistics, 2008). From 1996 to 2007 the production of chili in national level grew by about 9.15 percent with the main production area is Java Island that contributed by about 58.73 percent. Among provinces in Java Island, those three provinces, i.e. West Java, East Java and Central Java contributed around 22.48, 19.33 and 13.13 percent to the national production (Department of Agriculture, 2008 ${ }^{\mathrm{a}}$ ). It is expected that the production of chili will increase since the Indonesian population and consumption per capita of chili increase.

To capture the current market situation of chili, a scoping study was conducted in West Java and Central Java in August-September 2009. Several players were involved in the supply chain of red chili in Indonesia, i.e. farmers, collectors, wholesalers, food industries, modern retailers, traditional retailers and consumers. Collectors have an important position since around 60$70 \%$ of chili volume from farmers is delivered directly to collectors before being distributed to other middlemen who will deliver chili to food industries and retailers. Farmers and buyers are currently coordinating through production and marketing contracts. However, because substantial price fluctuations occur, supply chain participants have been unable to predetermine prices. Therefore, current contracts contain no price specifications. Chili prices will be determined by current market prices, thus both farmers and buyers are faced with price risk. Before a participant delivers chili to the next participants in the chili supply chain, he/she will collect the price 
information from the reference markets, i.e. major wholesale markets.

The traders in major wholesale markets explained that prices will be determined depend on daily situation of demand and supply of chili in these markets. For example, when a lot of chilies are delivered to major wholesale markets while demand in normal situation, then chili prices will decrease. Chili prices will increase when chili supply in the major wholesale markets decrease or when demand of chili increase particularly on the national big celebration, i.e. idul fitri. Similar situation occurs in modern market where chili prices from supplier to supermarket depend on market prices of chili in the major wholesale markets that will be renegotiation each week. The supermarket supplier receives chili payment from modern markets fortnightly.

In order to assess emerging market failures and potential equity implications for producers and consumers in the chili market, the main purpose of this paper is to investigate asymmetry price transmission between producer and consumer levels in Indonesia. The analysis will be focused on the three main production areas of chili in Indonesia, i.e. West Java, Central Java and East Java. Analyzing at a regional level is essential since most of previous studies focus on asymmetric price transmission only at national level. In fact, as Frey and Manera (2007) show the incidence of price asymmetry depends not only on the type of product but also the location of analysis.

\section{THERITICAL FRAMEWORK AND LITERATURE REVIEW}

An extensive literature has evolved dealing with price transmission issue mainly focused on commodities that significantly contribute to consumers' daily expenditure such as gasoline and agricultural products. Most of the studies have been conducted in developed countries by applying various econometric methods. Among those methods, the Houck model, the cointegration method and the threshold autoregressive specification are widely used in detecting price asymmetry (Reziti \& Panagopoulos, 2008).

Houck (1977) proposed a price asymmetry test by dividing of independent variables, i.e. farm (producer) prices into rising and falling phases. Kinnucan \& Forker (1987) adopted the Houck approach to test price asymmetry in dairy products in the United States and conclude the evidence of asymmetry in the farm-retail price transmission process with the speed of adjustment in the retailer level for price increase being faster than for a decrease in dairy prices. Aguiar \& Santana (2005) employ Houck's method for some agricultural products, i.e. tomatoes, onions, coffee, powdered milk, rice and beans in Brazil. Except onion and rice, the rest products under analysis are asymmetry with higher transmission rate for price increases. Capps \& Sherwell (2007) compare to two methods, i.e. Houck and von Cramon-Taubadel and Loy error correction model (ECM) to detect price asymmetry in milk products farm prices to retail prices in the seven cities in USA. Both methods conclude the existence of price asymmetry in the seven cities, except for the case of $2 \%$ of milk in Seattle.

von Cramon-Taubadel and Loy (1996) and von Cramon-Taubadel (1998) initiate cointegration techniques in testing price asymmetry that knowing as an error correction model (ECM). Similar to Houck method, the ECM has been utilized extensively by many authors and the conclusions of asymmetry price issues are inconclusive. Pfaff, et al., (2003) conclude the existence of price asymmetry at the producer-wholesale levels in the meat marketing channel in Germany, but no 
evidence of price asymmetry for the wholesale-retail levels. Bakucs \& Fertõ (2005) reject the existence of price asymmetry in Hungarian pork market. Cutts \& Kirsten (2006) find out asymmetric price in four South African agro-food industries, i.e. maize, wheat, sunflower and milk. Asche, et al. (2007) conclude asymmetry in the salmon price transmission process in Norway and UK. Reziti and Panagopoulos (2008) compare between a variants of ECM which is based on the Engle-Granger two-step estimation method (ECM-EG) and LSEHendry general to specific models (GETS) in testing asymmetry price in food, fruit and vegetable markets in Greek. Both models agree the existence price asymmetry in food, but reject price asymmetry in fruit markets. However, no unified conclusion between the two models in vegetable market where ECMEG rejects price asymmetry while GETS model concludes the evidence of price asymmetry.

The cointegration model that is utilized by authors above cannot capture non-linearity issue in price transmission mechanisms. In fact, as Balcombe et al. (2007) state there are two main factors leading to non-linearity of price exist, i.e. high transaction and transportation cost. Both can cause imperfect arbitrage and are examined whenever price differentials are larger than the cost of transaction (Koutroumanidis et al., 2009). Accordingly in such situation, some authors prefer to utilize threshold model to test the existence of nonlinear transaction costs and the incidence of price bands where there is no transmission (Reziti \& Panagopoulos, 2008). Early studies applying this model include asymmetric price in the Swiss pork market by Abdulai (2002); asymmetric price in farm-milled rice in Arkansas, Lousiana, California and Texas by No et al. (2004); and the evidence of threshold effects in Brazilian wheat, maize and soya prices by
Balcombe et al. (2007). Unfortunately, at an empirical level, the data required for the threshold model, i.e. transportation and transaction cost, are rarely available (Balcombe et al., 2007; Sanjua \& Gil, 2001). As a result many authors still prefer to apply both Houck's model and ECM to test the asymmetric price issue.

\section{METHODOLOGY}

\section{The econometric Model}

Due to the limitation of transportation and transaction cost data in the chili supply chain in Indonesia, the methods that will be employed in this paper are is Houck approach and a variant of ECM in Reziti and Panagopoulos (2008), i.e.ECM-EG. There are three stages applied in testing price asymmetry which based on the stages in Rao and Rao, (2005), Reziti and Panagopoulos (2008) and Capps and Sherwell (2007). First, the cointegration issue must be checked as well as the number of lags that will be included in each asymmetry equation. Second, the causality relationship between producer (farm) and consumer prices must be determined. After that asymmetry price in Indonesian chili supply chain will be analyzed by following Houck approach and ECM-EG.

\subsection{Cointegration issue}

The first stage is to verify the cointegration between producer price and consumer price series. The stationary price series data at producer and consumer level in each province are confirmed by applying the Augmented Dickey Fuller (ADF) test. Then for each price series that are cointegrated in same order, the application of the Johansen and Juselius, (1990) are used to test their cointegration as indicated in equation (1a) and (1b).

$$
P_{t}=\mu+\sum_{j=1}^{k} \Pi_{i} P_{t-1}+e_{t}
$$


where $P_{t}$ is vector of producer and consumer prices ( $\mathrm{PP}$ and $\mathrm{CP}$ ); and $e_{t}$ is Gaussian residuals

Re-parameterize the the equation (1a) into the VECM form (equation 1b) is needed to determine the rank of $\Pi$ and to reach the conclusion about the number of co-integration equations.

$$
\Delta P_{t}=c+\Pi P_{t-1}+\sum_{j=1}^{k-1} B_{j} \Delta P_{t-j}+\varepsilon_{t}
$$

where $\Pi$ is a matrix of long run and adjustment parameters; $B_{j}$ is matrix of the short-run parameter; $\varepsilon_{t}$ is vector of i.d; and jis the number of lags. Trace statistic will be used in testing the cointegration between producer and consumer prices for each province.

\subsection{Causality test}

Granger causality test is applied to investigate the causality between producer and consumer prices. Two equations are used in this step (equation $2 \mathrm{a}$ and $2 \mathrm{~b}$ ). In equation $2 \mathrm{a}$, a regression equation of the producer prices is run as a function of lagged producer and consumer prices. Equation $2 b$ is consisted of consumer prices as dependent variable and two independent variables, i.e. lagged consumer and producer prices. Those equations based on two-step methodology proposed by Granger and Engle (1987). Following Reziti and Panagopoulos (2008) and Koutroumanidis, et al. (2009), the causality test is concluded by applying a weak exogeneity test.

$\Delta P P_{t}=\mu_{1}+\sum_{i=1}^{n 1} \beta_{p p} \Delta P P_{t-i}+\sum_{i=0}^{n 2} \beta_{p c} \Delta C P_{t-i}+\pi_{1} Z_{t 1-1}+e_{t 1}$

and

$\Delta C P_{t}=\mu_{2}+\sum_{i=0}^{n 1} \beta_{p p} \Delta P P_{t-i}+\sum_{i=1}^{n 2} \beta_{p c} \Delta C P_{t-i}+\pi_{2} Z_{t 2-1}+e_{t 2}$
The conclusion is indicated below;

(i) if $\pi_{1} \neq 0$ and $\pi_{2} \neq 0$, there is a feedback long-run relationship between the two variables

(ii) if $\pi_{1}=0$ and $\pi_{2} \neq 0$, so $P P_{t}$ in the long-run causes $C P_{t}$

(iii) if $\pi_{1} \neq 0$ and $\pi_{2}=0$, so $C P_{t}$ in the long-run causes $P P_{t}$

\subsection{The issue of Asymmetry (ECM versus Houck's model)}

Supposed based in stage 2, assuming that PP cause PC, therefore the Houck approach can be written as follow:

$\Delta C P_{t}=\alpha_{0}+\alpha_{1} \Delta P P_{t}^{+}+\alpha_{2} \Delta P P_{t}^{-}+\varepsilon_{t}$

Where PP and PC are producer and consumer prices respectively. $\triangle P P_{t}^{+}=P P_{t}-P P_{t-1}$, if $P P_{t}>P P_{t-1}$ and 0 otherwise; $\Delta P P_{t}^{-}=P P_{t}-P P_{t-1}$, if $P P_{t}<$ $P P_{t-1}$ and 0 otherwise. Many literatures conclude that there is a time adjustment for producer price to change in the consumer price (Capps and Sherwell, 2007). As a result, a static model above can be re- specified as a dynamic model as follow (equation 6).

$\Delta C P_{t}=\alpha_{0}+\sum_{i=0}^{M 1} \alpha_{1 i} \Delta P P_{t-i}^{+}+\sum_{i=0}^{M 2} \alpha_{2 i} \Delta P P_{t-i}^{-}+\varepsilon_{t}$

The $\alpha_{1 i}$ coefficient corresponds to the impact of rising producer prices on consumer prices and the $\alpha_{2 \mathrm{i}}$ coefficientcorresponds to the impact of falling producer prices on consumer prices. A formal test of asymmetry hypothesis is indicated by equation (5). If the Ho is rejected then we conclude that there is asymmetric price transmission from consumer prices to producer prices.

$$
H_{0}: \sum_{i=0}^{M 1} \alpha_{1 i}=\sum_{i=0}^{M 2} \alpha_{2 i}
$$


The ECM-EG model has the following form:

$\Delta P P_{t}=\mu_{1}+\sum_{i=0}^{n 2} \beta^{-} P C \Delta C P^{-}{ }_{t-i}+\sum_{i=1}^{n 1} \beta_{P P}^{-} \Delta P P^{-}{ }_{t-i}+\pi_{1} Z_{t-1}^{-}+$

$\sum_{i=0}^{n 3} \beta_{P C}^{+} \Delta C P_{t-1}^{+}+\sum_{i=1}^{n 4} \beta_{P P}^{+} \Delta P P_{t-1}^{+}+\pi_{2} Z_{t-1}^{+}+\varepsilon_{t}$

The plus (+) superscripts on the coefficients and the variables indicate that changes in the variables are positives. The minus (-) superscript indicate that changes in the variables are negative (Rao and Rao, 2005). To test the existence of asymmetric price transmission hypothesis in equation (3) a formal F-test will be utilized as the null hypothesis indicate in equation (4). The evidence of the asymmetric price transmission in the chili supply chain is included if the null hypothesis is rejected.

$$
H_{0}: \pi_{1}=\pi_{2}
$$

\section{The data}

The chili price data at the producer and consumer levels from January 1990 to December 2007 in the three main production areas of chili in Java Island, i.e. West Java, Central Java and East Java provinces are utilized in the analysis. The chili prices at consumer level were deflated by the regional consumer's price index while the regional agricultural price indexes are utilized to deflate the chili prices at producer level. Those data are published by Indonesian Central Bureau of Statistics.

The producer and consumer prices utilized in this paper are expressed in terms of IDR per kilogram. Average real producer prices of chili ranged from IDR 5,417 per kilogram (West Java) to IDR 7,041 per kilogram (East Java). Average real consumer prices of chili ranged from IDR 13,299 per kilogram (Central Java) to IDR 17,583 (East Java). East Java has the highest level of coefficient of variation (Table 1). To reduce the variation of the data, we transform our data into natural logarithm form that would from economic perspective allow us to interpret the result in elasticity terms.

Table 1. Descriptive Statistics of Chili Prices at the Producer and Consumer Levels from January 1990 to December 2007 in the Three Provinces

\begin{tabular}{|c|c|c|c|c|c|c|c|}
\hline \multirow[b]{2}{*}{ Variable } & \multirow[b]{2}{*}{ Obs } & \multicolumn{3}{|c|}{ Real prices } & \multicolumn{3}{|c|}{ Natural Logarithm } \\
\hline & & Mean & Std. Dev. & $\mathrm{CV}^{\mathrm{a}}$ & Mean & Std. Dev. & $\mathrm{CV}^{\mathrm{a}}$ \\
\hline \multicolumn{8}{|l|}{ West Java } \\
\hline - Producer price $(\mathrm{PP})$ & 216 & 5,417 & 2,833 & 52.30 & 8.48 & 0.46 & 5.47 \\
\hline - Consumer price $(\mathrm{CP})$ & 216 & 13,522 & 10,393 & 76.86 & 9.27 & 0.69 & 7.41 \\
\hline \multicolumn{8}{|l|}{ Central Java } \\
\hline - Producer price $(\mathrm{PP})$ & 216 & 6,371 & 5,773 & 90.61 & 9.13 & 0.85 & 9.33 \\
\hline - Consumer price $(\mathrm{CP})$ & 216 & 13,299 & 12,707 & 95.55 & 8.51 & 0.65 & 7.66 \\
\hline \multicolumn{8}{|l|}{ East Java } \\
\hline - Producer price $(\mathrm{PP})$ & 216 & 7,041 & 6,560 & 93.17 & 8.61 & 0.64 & 7.48 \\
\hline - Consumer price $(\mathrm{CP})$ & 216 & 17,583 & 17,549 & 99.81 & 9.34 & 0.94 & 10.02 \\
\hline
\end{tabular}

\section{RESULT AND DISCUSSION}

The results of ADF indicate the presence of a unit root for all price series in levels. This indicates that stationarity has accomplished for all price series in levels. The trace statistic tests show that every pair of chili price series under consideration in the three provinces are cointegrated at the level one (Table 2). 
Table 2. Cointegration rank tests $\left(\lambda_{\text {Trace }}\right)$

The causality tests show that the values of F-test for $\mathbf{Z}_{\mathbf{t}-1}$ coefficients $\left(\pi_{1}\right.$ and $\pi_{2}$ ) in both equations are significant in the three provinces (Table 3). Therefore, we conclude the simultaneous relationship between producer and consumer prices in West Java, Central Java and East Java. The results differ from previous studies where most of them conclude that producer price cause consumer price, e.g. Kinnucan and Forker (1987), Aguiar and Santana
(2005), and Capps and Sherwell (2007). As a result for asymmetric test we estimate two equations for each province, i.e. one equation associated with consumer price causes producer price $(\mathrm{CP} \rightarrow \mathrm{PP})$ and one equation related to producer price causes consumer price $(\mathrm{PP} \rightarrow \mathrm{CP})$. Therefore, we have 12 equations associated with asymmetric price in the Houck and the ECM approaches.

Table 3. Granger causality results

\begin{tabular}{|c|c|c|c|c|}
\hline \multirow[t]{2}{*}{ Province } & \multirow[t]{2}{*}{ No. of lags } & \multicolumn{2}{|c|}{ Weak exogeneity } & \multirow[t]{2}{*}{ Causality results } \\
\hline & & $\begin{array}{c}\text { Price } 1 \\
H_{0}: \pi_{1}=0\end{array}$ & $\begin{array}{c}\text { Price } 2 \\
H_{0}: \pi_{2}=0\end{array}$ & \\
\hline West Java & 1 & $\begin{array}{r}5.42^{*} \\
(0.0209)\end{array}$ & $\begin{array}{r}7.57 * * \\
(0.0065)\end{array}$ & $\begin{array}{l}\mathrm{PP} \text { causes } \mathrm{CP} \text { and } \mathrm{CP} \\
\text { causes } \mathrm{PP}(\mathrm{PP} \leftrightarrow \mathrm{CP})\end{array}$ \\
\hline Central Java & 2 & $\begin{array}{r}9.45 * * \\
(0.0024)\end{array}$ & $\begin{array}{r}8.43 * * \\
(0.0041)\end{array}$ & $\begin{array}{l}\text { PP causes } \mathrm{CP} \text { and } \mathrm{CP} \\
\text { causes } \mathrm{PP}(\mathrm{PP} \leftrightarrow \mathrm{CP})\end{array}$ \\
\hline East Java & 1 & $\begin{array}{r}9.45 * * \\
(0.0024)\end{array}$ & $\begin{array}{r}8.43 * * \\
(0.0041)\end{array}$ & $\begin{array}{l}\mathrm{PP} \text { causes } \mathrm{CP} \text { and } \mathrm{CP} \\
\text { causes } \mathrm{PP}(\mathrm{PP} \leftrightarrow \mathrm{CP})\end{array}$ \\
\hline
\end{tabular}

*Significant at the $5 \%$ level and $* *$ significant at the $1 \%$ level

Table 4 and 5 presents the estimated coefficients and the estimated p-values concerning the Houck approach and the ECM-EG approach for both equations in the three provinces. In general, the Houck and ECM-EG approaches produce consistence parameter estimation both sign and size. At the level significance 5\%, variable associated with current time of the rising price variables and the declining price variables are significant. This finding indicates that the producer (or consumer) prices adjust with the changes in consumer (or producer) price at the same period. The number of lag associated with rising and declining price variables typically are one in West Java and East Java and two in Central Java.
With the Houck approach, the cumulative effect on the dependent variable of rising prices exceed the cumulative effect of falling prices occur at $\mathrm{PP} \rightarrow \mathrm{CP}$ equations in West Java and East Java; and at $\mathrm{CP} \rightarrow \mathrm{PP}$ equations in Central Java and East Java. In the other two equations $(\mathrm{CP} \rightarrow \mathrm{PP}$ in West Java and $\mathrm{PP} \rightarrow \mathrm{CP}$ in Central Java), the cumulative fall exceed the cumulative rise. However, in all equations in the Houck approach, the F-test values are insignificant at the level 5 percent, accepting the null hypothesis. Therefore, there is no evidence of price asymmetry between producer and consumer prices in the three provinces, over this data period. The price rises or falls pass on the same speed between producers and consumers in the three provinces. 
Table 4. Empirical results of Houck approach of chili in the three provinces, January 1990-December 2007

\begin{tabular}{|c|c|c|c|c|c|c|}
\hline & \multicolumn{2}{|c|}{ West Java } & \multicolumn{2}{|c|}{ Central Java } & \multicolumn{2}{|c|}{ East Java } \\
\hline & $\mathrm{CP} \rightarrow \mathrm{PP}$ & $\mathrm{PP} \rightarrow \mathrm{CP}$ & $\mathrm{CP} \rightarrow \mathrm{PP}$ & $\mathrm{PP} \rightarrow \mathrm{CP}$ & $\mathrm{CP} \rightarrow \mathrm{PP}$ & $\mathrm{PP} \rightarrow \mathrm{CP}$ \\
\hline \multirow[t]{2}{*}{ Intercept } & $0.012^{\mathrm{a}}$ & -0.028 & -0.003 & 0.033 & -0.009 & 0.004 \\
\hline & $(0.563)^{b}$ & $(0.112)$ & (0.908) & $(0.171)$ & $(0.718)$ & $(0.837)$ \\
\hline \multirow[t]{2}{*}{$\Delta \mathrm{CP}_{\mathrm{t}}^{-}$} & $0.452 *$ & & $0.522 *$ & & $0.492 *$ & \\
\hline & $(0.000)$ & & $(0.033)$ & & $(0.000)$ & \\
\hline \multirow[t]{2}{*}{$\Delta \mathrm{CP}_{\mathrm{t}-1}^{-}$} & 0.045 & & 0.097 & & 0.081 & \\
\hline & $(0.532)$ & & $(0.148)$ & & $(0.235)$ & \\
\hline \multirow[t]{2}{*}{$\Delta \mathrm{CP}_{\mathrm{t}-2}^{-}$} & & & -0.029 & & & \\
\hline & & & $(0.908)$ & & & \\
\hline \multirow[t]{2}{*}{$\Delta \mathrm{PP}_{\mathrm{t}}^{-}$} & & $0.864^{*}$ & & 1.004 & & $0.926 *$ \\
\hline & & $(0.000)$ & & $(0.000)^{*}$ & & $(0.000)$ \\
\hline \multirow[t]{2}{*}{$\Delta \mathrm{PP}_{\mathrm{t}-1}^{-}$} & & -0.046 & & 0.024 & & -0.100 \\
\hline & & (0.694) & & $(0.821)$ & & $(0.227)$ \\
\hline \multirow[t]{2}{*}{$\Delta \mathrm{PP}_{\mathrm{t}-2}^{-}$} & & & & 0.062 & & \\
\hline & & & & $(0.547)$ & & \\
\hline \multirow[t]{2}{*}{$\Delta \mathrm{CP}^{+}{ }_{\mathrm{t}}$} & $0.324 *$ & & 0.463 & & 0.549 & \\
\hline & $(0.000)$ & & $(0.000)^{*}$ & & $(0.000)^{*}$ & \\
\hline \multirow[t]{2}{*}{$\Delta \mathrm{CP}_{\mathrm{t}-1}^{+}$} & 0.096 & & 0.014 & & 0.120 & \\
\hline & $(0.123)$ & & $(0.845)$ & & (0.113) & \\
\hline$\Delta \mathrm{CP}^{+}{ }_{\mathrm{t}-2}$ & & & $0.155^{*}$ & & & \\
\hline \multirow[t]{2}{*}{$\Delta \mathrm{PP}^{+}{ }_{\mathrm{t}}$} & & $1.054^{*}$ & & $0.980 *$ & & $0.979 *$ \\
\hline & & $(0.000)$ & & $(0.000)$ & & $(0.000)$ \\
\hline \multirow[t]{2}{*}{$\Delta \mathrm{PP}^{+}{ }_{\mathrm{t}-1}$} & & -0.030 & & -0.030 & & -0.032 \\
\hline & & $(0.615)$ & & $(0.684)$ & & $(0.581)$ \\
\hline$\Delta \mathrm{PP}^{+}{ }_{\mathrm{t}-2}$ & & & & $\begin{array}{r}-0.159^{*} \\
(0.032)\end{array}$ & & \\
\hline $\begin{array}{l}\text { Cumulative } \\
\text { falls }\end{array}$ & 0.497 & 0.818 & 0.590 & 1.090 & 0.573 & 0.826 \\
\hline $\begin{array}{l}\text { Cumulative } \\
\text { rises }\end{array}$ & 0.420 & 1.024 & 0.632 & 0.791 & 0.669 & 0.947 \\
\hline $\mathrm{R}^{2}$ & 0.356 & 0.690 & 0.435 & 0.6512 & 0.416 & 0.728 \\
\hline $\mathrm{R}^{2}$-adj & 0.343 & 0.684 & 0.412 & 0.6410 & 0.404 & 0.722 \\
\hline F-test for & 0.22 & 1.00 & 0.05 & 1.66 & 0.35 & 0.55 \\
\hline symmetry & $(0.638)$ & $(0.319)$ & $(0.825)$ & (0.199) & $(0.558)$ & $(0.459)$ \\
\hline
\end{tabular}

${ }^{\mathrm{a}}$ parameter estimate

$\mathrm{bp}_{\text {-value }}$

In ECM-EG approach, only the cumulative effect on the dependent variables of declining prices $\left(\pi^{-}\right)$in Central Java and East Java at $\mathrm{PC} \rightarrow \mathrm{PP}$ equations significant at $5 \%$ level. At the same significant level, no cumulative effect associated with rising prices $\left(\pi^{+}\right)$ is significant for all equations in each provinces. Similar to Houck approach, the Wald test reject asymmetry price between producer (consumer) and consumer (producer) prices where the null hypothesis is accepted by all equations in the three provinces. Price falls are passed in the same speed with price rises.

The result from both Houck and ECM-EG approaches agree in terms of rejecting price asymmetry issue in the chili supply chain in the three provinces. 
Similarly, Aguiar and Santana (2005) conclude asymmetry price in onion and rice in Brazil as well as the Reziti and Panagopoulos (2008) study that report asymmetry price in fruits and vegetables markets in Greek. As a perishable product which has a large price fluctuation, both producers and consumers of chili in Indonesia will refer to reference markets in determining chili prices. The supply chain participants both in modern markets and traditional markets are unable to predetermine chili prices in their current market contract. Therefore, price changes from consumer level will be transmitted at the same speed to producer level as well as increasing prices or decreasing prices from producer level to consumer level.

Table 5. Empirical results of ECM approach of chili in the three provinces, January 1990 December 2007

\begin{tabular}{|c|c|c|c|c|c|c|}
\hline & \multicolumn{2}{|c|}{ West Java } & \multicolumn{2}{|c|}{ Central Java } & \multicolumn{2}{|c|}{ East Java } \\
\hline & $\mathrm{CP} \rightarrow \mathrm{PP}$ & $\mathrm{PP} \rightarrow \mathrm{CP}$ & $\mathrm{CP} \rightarrow \mathrm{PP}$ & $\mathrm{PP} \rightarrow \mathrm{CP}$ & $\mathrm{CP} \rightarrow \mathrm{PP}$ & $\mathrm{PP} \rightarrow \mathrm{CP}$ \\
\hline \multirow[t]{2}{*}{ Intercept } & $0.023^{\mathrm{a}}$ & -0.007 & 0.005 & 0.026 & -0.024 & 0.076 \\
\hline & $(0.337)^{b}$ & $(0.845)$ & $(0.868)$ & $(0.599)$ & $(0.496)$ & $(0.181)$ \\
\hline \multirow[t]{2}{*}{$\Delta \mathrm{CP}_{\mathrm{t}}^{-}$} & $0.427 *$ & & $0.504 *$ & & $0.476^{*}$ & \\
\hline & $(0.000)$ & & $(0.000)$ & & $(0.000)$ & \\
\hline \multirow[t]{2}{*}{$\Delta \mathrm{CP}_{\mathrm{t}-1}^{-}$} & 0.003 & -0.059 & -0.055 & -0.155 & 0.060 & -0.135 \\
\hline & $(0.975)$ & $(0.641)$ & $(0.516)$ & $(0.137)$ & $(0.609)$ & (0.188) \\
\hline \multirow[t]{2}{*}{$\Delta \mathrm{CP}_{\mathrm{t}-2}^{-}$} & & & -0.003 & 0.102 & & \\
\hline & & & $(0.972)$ & $(0.368)$ & & \\
\hline \multirow[t]{2}{*}{$\Delta \mathrm{PP}_{\mathrm{t}}^{-}$} & & $1.225^{*}$ & & $1.106^{*}$ & & $1.049 *$ \\
\hline & & $(0.000)$ & & $(0.000)$ & & $(0.000)$ \\
\hline \multirow[t]{2}{*}{$\Delta \mathrm{PP}_{\mathrm{t}-1}^{-}$} & 0.157 & -0.044 & 0.079 & 0.056 & 0.062 & -0.001 \\
\hline & $(0.223)$ & $(0.823)$ & $(0.546)$ & $(0.750)$ & $(0.609)$ & (0.996) \\
\hline \multirow[t]{2}{*}{$\Delta \mathrm{PP}_{\mathrm{t}-2}^{-}$} & & & -0.012 & -0.010 & & \\
\hline & & & $(0.926)$ & $(0.953)$ & & \\
\hline \multirow[t]{2}{*}{$\Delta \mathrm{CP}^{+}{ }_{\mathrm{t}}$} & $0.327 *$ & & $0.446^{*}$ & & $0.529 *$ & \\
\hline & $(0.000)$ & & $(0.000)$ & & $(0.000)$ & \\
\hline \multirow[t]{2}{*}{$\Delta \mathrm{CP}_{\mathrm{t}-1}^{+}$} & 0.118 & $-0.178 * *$ & -0.013 & -0.032 & 0.130 & $-0.204 * *$ \\
\hline & $(0.086)$ & $(0.092)$ & $(0.876)$ & (0.778) & (150) & (0.069) \\
\hline \multirow[t]{2}{*}{$\Delta \mathrm{CP}_{\mathrm{t}-2}^{+}$} & & & $0.147 * *$ & -0.132 & & \\
\hline & & & $(0.081)$ & $(0.243)$ & & \\
\hline \multirow[t]{2}{*}{$\Delta \mathrm{PP}^{+}{ }_{\mathrm{t}}$} & & $0.746^{*}$ & & $0.698^{*}$ & & $0.638 *$ \\
\hline & & $(0.000)$ & & $(0.000)$ & & $(0.000)$ \\
\hline \multirow[t]{2}{*}{$\Delta \mathrm{PP}_{\mathrm{t}-1}^{+}$} & -0.137 & $0.349^{*}$ & -0.037 & 0.122 & -0.134 & 0.146 \\
\hline & $(0.152)$ & $(0.020)$ & $(0.715)$ & $(0.362)$ & $(0.208)$ & $(0.262)$ \\
\hline \multirow[t]{2}{*}{$\Delta \mathrm{PP}_{\mathrm{t}-2}^{+}$} & & & -0.091 & -0.064 & & \\
\hline & & & $(0.386)$ & $(0.642)$ & & \\
\hline \multirow[t]{2}{*}{$\pi^{-}$} & -0.052 & $-0.135 * *$ & $-0.182 *$ & $-0.169 * *$ & $-0.217^{*}$ & 0.010 \\
\hline & (0.359) & $(0.058)$ & (0.004) & $(0.094)$ & (0.009) & $(0.907)$ \\
\hline \multirow[t]{2}{*}{$\pi^{+}$} & -0.067 & -0.032 & -0.035 & -0.053 & -0.358 & $-0.118^{* *}$ \\
\hline & $(0.229)$ & (0.554) & $(0.555)$ & $(0.370)$ & $(0.546)$ & $(0.061)$ \\
\hline $\mathrm{R}^{2}$ & 0.383 & 0.393 & 0.477 & 0.476 & 0.046 & 0.458 \\
\hline $\mathrm{R}^{2}$-adj & 0.359 & 0.370 & 0.446 & 0.444 & 0.439 & 0.437 \\
\hline F-test for & 0.03 & 0.88 & 2.23 & 0.69 & 2.22 & 0.83 \\
\hline symmetry & $(0.873)$ & $(0.350)$ & (0.137) & $(0.408)$ & $(0.138)$ & $(0.363)$ \\
\hline
\end{tabular}

${ }^{\mathrm{a}}$ parameter estimate

b p -value 
Short run and long run elasticities for increases and decreases both in $\mathrm{CP} \rightarrow \mathrm{PP}$ and $\mathrm{PP} \rightarrow \mathrm{CP}$ equations are presented in Table 6 (Houck approach) and in Table 7 (ECM-EG approach). With the Houck approach, the short run elasticities are the coefficients of current differencing of falling and rising prices, $\alpha_{1 t}$ and $\alpha_{2 t}$, while the long-run elasticities are calculated from the summation of all coefficients associated price falls or price rises. Similar to Houck approach, the short run elasticities of the ECM-EG approach are obtained from the coefficients of current differencing of falling and rising prices. Meanwhile, the long run elasticities are calculated from the coefficient of price in the first stage of ECM-EG equation (Reziti and Panagopoulos, 2008).

Both approaches provide short run and long run elasticities greater in $\mathrm{PP} \rightarrow \mathrm{CP}$ equation rather than those in $\mathrm{CP} \rightarrow \mathrm{PP}$ equations. It indicates that rising or declining prices in producer level will be adjusted to consumer level bigger than adjusting of rising or declining prices from consumer level to producer level. For example for a Houck model, a $10 \%$ increase in the producer price of chili in West Java in short run causes $10.54 \%$ increase in consumer price while in $\mathrm{CP} \rightarrow \mathrm{PP}$ equation, a $10 \%$ increase in consumer price of chili causes $3.24 \%$ increase in producer price. Moreover, in $\mathrm{CP} \rightarrow \mathrm{PP}$ equation of both approaches, short run elasticities associated with rising prices are greater than declining prices except in East Java. While in $\mathrm{PP} \rightarrow \mathrm{CP}$ equation in both approaches, short run elasticities associated with rising prices are greater than declining prices except in Central Java.

It is interesting to note that the long run elasticities in the Houck approach for PP $\rightarrow$ CP seem lower than those in short run. Such situations happen since there is a trade off impact of dependent variables at current time and their lag. For instance based on value from Table 4 at $\mathrm{PP} \rightarrow \mathrm{CP}$ equation in West Java, a $10 \%$ increase in producer price of chili causes an instantaneous $10.54 \%$ increase in consumer price and a $0.3 \%$ decrease after one months. However, for $\mathrm{CP} \rightarrow \mathrm{PP}$ equation the long run elasticities are higher than those in the short run. With the ECM approach, the long run elasticities seem higher than short run elasticities in both equations.

Table 6. Elasticities of price transmission of chili with the Houck approach

\begin{tabular}{llcccc}
\hline Province & Variable & \multicolumn{2}{c}{ Short-Run Elasticity } & \multicolumn{2}{c}{ Long-Run Elasticity } \\
\cline { 2 - 6 } & & $\mathrm{CP} \rightarrow \mathrm{PP}$ & $\mathrm{PP} \rightarrow \mathrm{CP}$ & $\mathrm{CP} \rightarrow \mathrm{PP}$ & $\mathrm{PP} \rightarrow \mathrm{CP}$ \\
\hline \multirow{6}{*}{ West Java } & $\Delta \mathrm{PP}^{+}$ & - & 1.054 & - & 1.024 \\
& $\Delta \mathrm{CP}^{+}$ & 0.324 & - & 0.420 & - \\
& $\Delta \mathrm{PP}^{-}$ & - & 0.864 & - & 0.818 \\
& $\Delta \mathrm{CP}^{-}$ & 0.452 & - & 0.497 & - \\
& $\Delta \mathrm{PP}^{+}$ & - & 0.980 & - & 0.791 \\
\multirow{6}{*}{ Central Java } & $\Delta \mathrm{CP}^{+}$ & 0.463 & - & 0.632 & - \\
& $\Delta \mathrm{PP}^{-}$ & - & 1.004 & - & 1.090 \\
& $\Delta \mathrm{CP}^{-}$ & 0.522 & - & 0.590 & - \\
& $\Delta \mathrm{PP}^{+}$ & - & 0.979 & - & 0.947 \\
\multirow{6}{*}{ East Java } & $\Delta \mathrm{CP}^{+}$ & 0.549 & - & 0.669 & - \\
& $\Delta \mathrm{PP}^{-}$ & - & 0.926 & - & 0.826 \\
& $\Delta \mathrm{CP}^{-}$ & 0.492 & - & 0.573 & - \\
\hline
\end{tabular}


Table 7. Elasticities of price transmission of chili with the ECM-EG approach

\begin{tabular}{llcccc}
\hline Province & Variable & \multicolumn{2}{c}{ Short-Run Elasticity } & \multicolumn{2}{c}{ Long-Run Elasticity } \\
\cline { 2 - 5 } & & $\mathrm{CP} \rightarrow \mathrm{PP}$ & $\mathrm{PP} \rightarrow \mathrm{CP}$ & $\mathrm{CP} \rightarrow \mathrm{PP}$ & $\mathrm{PP} \rightarrow \mathrm{CP}$ \\
\hline \multirow{4}{*}{ West Java } & $\Delta \mathrm{PP}^{+}$ & - & 0.746 & 0.384 & 0.843 \\
& $\Delta \mathrm{CP}^{+}$ & 0.327 & - & & \\
& $\Delta \mathrm{PP}^{-}$ & - & 1.225 & & \\
& $\Delta \mathrm{CP}^{-}$ & 0.427 & - & & \\
& $\Delta \mathrm{PP}^{+}$ & - & 0.698 & 0.607 & 1.034 \\
\multirow{6}{*}{ Central Java } & $\Delta \mathrm{CP}^{+}$ & 0.446 & - & & \\
& $\Delta \mathrm{PP}^{-}$ & - & 1.106 & & \\
& $\Delta \mathrm{CP}^{-}$ & 0.504 & - & & \\
& $\Delta \mathrm{PP}^{+}$ & - & 0.638 & 0.487 & 1.028 \\
& $\Delta \mathrm{CP}^{+}$ & 0.529 & - & & \\
& $\Delta \mathrm{PP}^{-}$ & - & 1.049 & & \\
& $\Delta \mathrm{CP}^{-}$ & 0.476 & - & & \\
\hline \multirow{6}{*}{ East Java } & & & & &
\end{tabular}

\section{CONCLUSION}

Under the rapid development of modern market chains in Indonesia, it is commonly believe that their existence will increase market power and influencing prices leading to the asymmetry issue in the chili supply chain. By comparing the Houck and ECM-EG approach, the empirical results show cointegration between producer and consumer prices in all provinces. Granger causality tests indicate a feedback long run relationship between producer and consumer prices in each province. Both methods agree that there is no existence of price asymmetry in any of the three provinces. Therefore, under period of analysis by using monthly data, price efficiency occurred in the chili market in Indonesia.

Since chili including as one of perishable product that have a tendency to be market quickly, monthly data may not cover very intense of declining or rising prices in the market. Aguiar and Santana (2005) support this view as they indicate that by the use of monthly data in perishable products might have skewed the results. Therefore, for the next study it would be better to clarify asymmetric price in chili supply chain in Indonesia by utilizing weekly price data.

Further, as commonly observed, price volatility and disparity remain a major issue for chili in domestic market so that the evidence of price efficiency is necessarily considered for policy formulation. Center for Domestic Trade Policy (2011) highlights the price stability in consumer level has been the main concern of the government. Therefore, trade policy that is formulated to address this issue shall behold the fact that the transmission in consumer price to producer price is greatly higher than the vice versa.

\section{REFERENCES}

Abdulai, A. 2002. Using threshold cointegration to estimate asymmetric price transmission in the Swiss pork market. Applied Economics, 34, 679-687.

Aguiar, D.R.D., and Santana, J.A. 2005. Asymmetry in farm to retail price transmission; evidence from Brazil. Agribusiness, 21(2), 273286.

Asche, F., Shabbar Jaffry, S., and Hartmann, J. 2007. Price transmission and market integration: vertical and horizontal price linkages for salmon. Applied Economics, 39(2535-2545).

Bakucs, L.Z., and Fertõ, I. 2005. Marketing margins and price 
transmission on the Hungarian pork meat market. Agribusiness, 21(2), 273-286.

Balcombe, K., Bailey, A., and Brooks, J. 2007. Threshold effects in price transmission: the case of Brazilian wheat, maize, and soya prices. American Journal of Agricultural Economics, 89(2), 308-323.

Capps, O., and Sherwell, P. 2007. Alternative approaches in detecting asymmetry in farmretail price transmission of fluid milk. Journal of Agribusiness, 23(3), 313-331.

Center for Domestic Trade Policy. 2011. Price disparity in chili market. Trade Policy Analysis and Development Agency, The Ministry of Trade, Jakarta.

Central Bureau of Statistics. 2008. Statistics Indonesia. Central Bureau of Statistics, Jakarta.

Central Bureau of Statistics. From various years. 2003-2008 . Producer price statistics of agricultural sector in Indonesia. Central Bureau of Statistics, Jakarta.

Central Bureau of Statistics. From various years. 2003-2008 ${ }^{\mathrm{b}}$. Consumer price statistics in Indonesia. Central Bureau of Statistics, Jakarta.

Cutts, M., and Kirsten, J. 2006. Asymmetric price transmission and market concentration: an investigation into four South African agro-food industries South African Journal of Economics, 74(2), 323-333.

Department of Agriculture. From various years, 1995-2008. Agricultural statistics. Department of Agriculture, Jakarta.
Department of Agriculture. 2003. Agricultural statistics. Department of Agriculture, Jakarta.

Department of Agriculture. 2008 . Outlook of agricultural commodities (horticulture). Department of Agriculture, Jakarta.

Department of Agriculture. $2008^{\mathrm{b}}$. Agricultural statistics. Department of Agriculture, Jakarta.

Frey, G., and Manera, M. 2007. Econometric models of asymmetric price transmission. Journal of Economic Surveys, 21(2), 349-415.

Granger, C.W.J., and Engle, R.F. 1987. Cointegration and Error Correction: representation, estimation and testing. Econometrica, 55(251-276).

Houck, P.J. 1977. An approach to specifying and estimating nonreversible functions. American Journal of Agricultural Economics, 59,570-572.

Johansen, S., and Juselius, K. 1990. Maximum likelihood estimation and inference on cointegrationwith applications to the demand for money. Oxford Bulletin of Economics and Statistics, 52, 169-210.

Kinnucan, H.W., and Forker, O.D. 1987. Asymmetry in farm-retail price transmission for major dairy products. American Journal of Agricultural Economics, 69, 285292.

Koutroumanidis, T., Zafeiriou, E., and Arabatzis, G. 2009. Asymmetry in price transmission between the producer and the consumer prices in the wood sector and the role of imports: the case of Greece. 
Forest Policy and Economics, 11, 56-64.

Meyer, J., and v. Cramon-Taubadel, S. 2004. Asymmetric price transmission: a survey. Journal of Agricultural Economics, 55(3), 581-611.

Miller, D.J., and Hayenga, M.L. 2001. Price cycles and asymmetric price transmission in the US Pork Market. American Journal of Agricultural Economics, 83(3), 551-562.

No, S.C., Zapata, H.O., Salassi, M.E., and Gauthier, W.M. 2004. Asymmetry in farm-milled rice price transmission in the major rice producing states in the U.S. The Journal of AmericanAcademy of Business, March, 460-463.

Pandin, M.I. 2009. The potraite of retail Business in Indonesia: Retail modern. Economic Review, 215.

Pfaff, K., Anders, S., and Herrmann, R. 2003. Processing costs and price transmission in the meat marketing chain: analysis for a German region. Journal of International Food and Agribusiness Marketing, 151(1/2), 7-22.

Reardon, T., and Berdegué, J.A. 2002. The rapid rise of supermarkets in Latin America: challenges and opportunities for development. Development Policy Review, 20(4), 371-388.

Reardon, T., Timmer, P., and Bordegue, J. 2004. The rapid rise of supermarkets in developing countries: induces organizational, institutional, and technological change in agrifood systems. Journal of Agricultural and Development Economics, 1(2), 168-183.

Rao, B.B., and Rao, G. 2005. Are U.S. gasoline price adjustments asymmetric? , Working Paper (pp. 1-9): Department of Economics, The University of South Pacific, Suva.

Reziti, I., and Panagopoulos, Y. 2008. Asymmetric price transmission in the Greek agri-food sector: some tests. Agribusiness, 24(1), 16-30.

Sanjua, A.I., and Gil, J.M. 2001. Price transmission analysis: a flexible methodological approach applied to European pork and lamb markets. Applied Economics, 33, 123-131.

v. Cramon-Taubadel, S., and Loy, J.P. 1996. Price Asymmetry in the international wheat market: comment. Canadian Journal of Agricultural Economics, 44, 311317

von Cramon-Taubadel, S. 1998. Estimating asymmetric price transmission with the error correction representation: an application to the German pork market European Review of Agricultural Economics, 25, 118.

Weatherspoon, D.D., and Reardon, T. 2003. The rise of supermarkets in Africa: implications for agrifood systems and the rural poor. Development Policy Review, 21(3), 333-355. 